\title{
ВПЛИВ ВІНБОРОНУ НА АНАЛГЕТИЧНУ АКТИВНІСТЬ ІБУПРОФЕНУ НА МОДЕЛІ АД'ЮВАНТНОГО АРТРИТУ У ЩУРІВ
}

\author{
(СФ. В. Гладких, Н. Г. Степанюк
}

\author{
Вінницький національний медичний університетімені М. І. Пирогова
}

РЕЗЮМЕ. Експериментально встановлено, що вінборон здатен потенціювати аналгетичну активність ібупрофену при лікуванні ад'ювантного артриту (AA) у щурів. На це вказувало зростання порогу больово чутливості на 28 добу експерименту при лікуванні АА комбінацією ібупрофену з вінбороном, який вдвічі перевищував аналогічний показник при монотерапі ібупрофеном. Крім того, вінборон показав спроможність послаблювати ульцерогенний ефект ібупрофену, про що свідчили динаміка маси тіла, виразковий індекс та відсутність летальності тварин. КЛЮЧОВІ СЛОВА: ад'ювантний артрит, НПЗЗ, ібупрофен, вінборон, аналгетична активність.

Вступ. Ефективне купірування больового синдрому $є$ першочерговим завданням фармакотерапі хворих ревматологічного профілю. Особливе значення в комплексному лікуванні гострих і хронічних захворювань опорно-рухово системи, при яких біль та запалення виступають основними клінічними проявами, належить нестеро дним протизапальним засобам (НПЗ3). Біль, що супроводжує ураження суглобів і періартикулярних тканин при ревмато дному артриті (РА), остеоартрозі (OA), анкілозуючому спондилоартриті та остеохондрозі хребта, обумовлений синтезом медіаторів, важливе місце серед яких належить простагландинам (ПГ), які активно утворюються у вогнищі ушкодження за участі ферменту циклооксигенази (ЦОГ) $[1,2]$. ПГ відповідають за розвиток локального набряку, підвищення проникності судин, порушення мікроциркуляці, хемотаксис клітин та безпосередньо впливають на процеси виникнення та передачі больового імпульсу, викликаючи підвищення чутливості периферійних ноцицептивних та аферентних нейронів задніх рогів спинного мозку. Цей механізм має універсальний характер у патогенезі больового синдрому та виступає підґрунтям для застосування в комплексній аналгетичній терапі НПЗЗ, які блокують ЦОГ та пригнічують синтез прозапальних ПГ [3, 4].

Відомо, що аналгезуючий ефект НПЗЗ проявляється при болях слабко та середньо інтенсивності, які локалізуються в м'язах, суглобах, сухожилках та нервових стовбурах. Систематично НПЗ3 застосовують перш за все хворі на РА, на частку яких припадає 68,5\%. Рідше призначають НПЗ3 при ОА (12,1\%), анкілозуючому спондилоартриті, остеохондрозі хребта; при системних захворюваннях сполучно тканини (системний червоний вовчак, склеродермія, дерматоміозит), при неврозах та невралгіях [5, 6, 7]. Швидкість досягнення та стійкість аналгетичного ефекту виступають основними критеріями адекватності лікування.

Тому при призначенні фармакотерапі пацієнтам ревматологічного профілю слід оцінити безпечність обраного антифлогістика та вжити оптимальних заходів для послаблення його побічних ефектів [8].

Найпридатнішим препаратом серед НПЗ3, який широко застосовується при тривалому лікуванні різноманітних запальних та дегенеративних захворювань опорно-рухового апарату, $є$ ібупрофен. На нашу думку, комбіноване застосування ібупрофену з вінбороном - новим вітчизняним спазмолітиком з політропними фармакологічними ефектами, дозволить не тільки покращити профіль безпечності вказаного НПЗЗ, а й матиме сприятливий вплив на коморбідний фон хворого [9].

Мета: охарактеризувати вплив вінборону на аналгетичний ефект ібупрофену на моделі ад'ювантного артриту (AА) у щурів.

Матеріали і методи дослідження. Дослідження проведено на 28 статевозрілих щурахсамцях, поділених на 4 групи: I - інтактні щури $(n=7)$, II - щури зі змодельованим AA (n=7) без лікування (контроль), III - щури з АA (n=5-7), ліковані ібупрофеном (218 мг/кг, в/ш), IV - щури з AA $(n=7)$, ліковані ібупрофеном (218 мг/кг, в/ш) В комбінаці з вінбороном (11 мг/кг, в/ш). Вінборон, розчинений у $0,9 \%$ розчині $\mathrm{NaCl}$, вводили за 60 хв до ібупрофену. Ібупрофен вводили внутрішньошлунково у вигляді завису на 3 \% крохмальному слизі двічі на добу (109 мг/Кг на один прийом).

Вказані препарати застосовували в середньотерапевтичних дозах для людини, запозичених 3 літературних джерел [10, 11]. Перерахунок препаратів з дози людини на щурів здійснювали із використанням коефіцієнта видово чутливості за Ю. Р. Риболовлєвим [12].

AА моделювали шляхом субплантарного [13] введення повного ад'юванту Фрейнда (Imject Freund's Complete Adjuvant, Thermo Scientific) в задню праву лапку з розрахунку 0,1 мл на щура («Доклінічні дослідження» за ред. О. В. Стефанова, 2002). День введення ад'юванту вважали як «0» день експерименту. Максимальний прояв місцево запально реакці, яка супроводжувалась значним збільшенням об'єму кінцівки, визначався на 12- 
Оеляди літератури, ориаінальні дослідження, поеляд на проблему

14 добу [14, 15], далі активність процесу поступово зменшувалась. Лікування АА проводили з 14 по 28 день, шляхом внутрішньошлункового введення досліджуваних препаратів. Початок введення лікарських засобів відповідав максимальній запальній реакці. Оцінку ефективності лікування проводили на 28 добу експерименту.

Аналгетичну активність оцінювали за значенням порогу больово чутливості. Больову реакцію викликали шляхом електроімпульсного подразнення слизово оболонки прямо кишки від лабораторного електроімпульсного стимулятора ЕСЛ-1.

Розвиток запально реакці оцінювали за динамікою товщини лапки, яку вимірювали за допомогою онкометра за О. С. Захаревським [16]. Дослідження проводили до введення ад'юванту (1 доба) на 14 та 28 добу експерименту.

Стан СОШ оцінювали макроскопічно (колір, складчастість, наявність слизу, ерозій, крововиливів, виразкових дефектів та перфоративних ви- разок) за бальною шкалою Л. В. Яковлево [17]. Для кожно групи досліджуваних тварин розраховували виразковий індекс (BI) за формулою: $\mathrm{Bl}=$ ступінь виразки $\times$ \% тварин з виразками / 100 .

Протягом дослідження контролювали динаміку маси тіла та показники летальності щурів в кожній групі.

Цифрові дані обробляли методом варіаційно статистики з використанням t-критерію Стьюдента, на комп'ютері за допомогою програм MS Excel 2007. Достовірними вважали зміни при рівні вірогідності $95 \%(p \leq 0,05)$.

Результати й обговорення. Результати проведеного дослідження показали, що введення ад'юванту тваринам контрольно групи призвело до статистично вірогідного зменшення ПБЧ на 14 добу експерименту на 18,6 \%, відносно початкового показника. Незначне зменшення ПБЧ на 7,4\% у тварин дано групи відмічалось на 28 добу, відносно 14 дня експерименту (табл. 1).

Таблиця 1. Характеристика ПБЧ у щурів з АА при лікуванні ібупрофеном та його комбінацією з вінбороном

\begin{tabular}{|c|c|c|c|c|c|c|c|}
\hline \multirow[b]{2}{*}{ Умови досліду } & \multirow[b]{2}{*}{$\mathrm{n}$} & \multirow{2}{*}{$\begin{array}{c}1 \text { доба, } \\
\text { ПБЧ, мВ }\end{array}$} & \multicolumn{2}{|c|}{ На 14 добу експерименту } & \multicolumn{3}{|c|}{ На 28 добу експерименту } \\
\hline & & & ПБЧ, мВ & $\begin{array}{c}\% \text { відносно } \\
1 \text { доби }\end{array}$ & ПБЧ, мВ & $\begin{array}{c}\text { \% відносно } \\
1 \text { доби }\end{array}$ & $\begin{array}{c}\text { \% відносно } \\
14 \text { доби }\end{array}$ \\
\hline $\begin{array}{l}\text { I група } \\
\text { Інтакт }\end{array}$ & 7 & $5,59 \pm 0,42$ & $5,6 \pm 0,45$ & $+0,3$ & $5,57 \pm 0,45$ & $-0,3$ & $-0,5$ \\
\hline $\begin{array}{c}\text { II група } \\
\text { (АА) } \\
\text { Контроль }\end{array}$ & 7 & $6,16 \pm 0,42$ & $5,01 \pm 0,39$ & $-18,6$ & $4,64 \pm 0,15 \epsilon$ & $-24,6$ & $-7,4$ \\
\hline $\begin{array}{c}\text { III група } \\
\text { АA } \\
\text { +Ібупрофен } \\
\end{array}$ & 7 & $5,97 \pm 0,68^{\#}$ & $5,09 \pm 0,76^{* \# \circ}$ & $-14,8$ & $6,92 \pm 0,85^{* \#}$ & $+15,9$ & $+36,1$ \\
\hline $\begin{array}{c}\text { IV група } \\
\text { АA } \\
+ \text { +Ібупрофен } \\
+ \text { +Вінборон }\end{array}$ & 7 & $5,54 \pm 0,6^{\#}$ & $4,31 \pm 0,33 *^{*_{0}}$ & $-22,2$ & $7,71 \pm 0,76^{\#} \boldsymbol{\epsilon}$ & $+39,2$ & $+78,8$ \\
\hline
\end{tabular}

Примітки:

1. * - p $\leq 0,05$ відносно початкового показника (1 доба експерименту);

2. \# - $\mathrm{p} \leq 0,05$ відносно контролю;

3. ${ }^{\circ}$ - $\mathrm{p} \leq 0,05$ відносно монотерапі ібупрофеном.

Подібна картина на 14 добу експерименту визначалась у III групі тварин (АА, лікований ібупрофеном), де показник ПБЧ статистично вірогідно зменшився відносно початкового показника на 14,8 \%. Однак лікування тварин III групи, починаючи з 14 доби, ібупрофеном, привело до статистично вірогідного збільшення ПБЧ на 28 добу експерименту на $16 \%$, відносно початкового рівня, та на 36,1\% відносно 14 дня експерименту. Отримані результати відповідають літературним даним про виразну аналгетичну активність ібупрофену в лікуванні хронічних дегенеративних захворювань сполучно тканини $[18,19]$.

Однак найвиразніші зміни ПБЧ відмічались у групі тварин, лікованих комбінацією ібупрофену з вінбороном, з 14 доби експерименту. На це вказувало статистично вірогідне збільшення ПБЧ на 28 добу дослідження на 39,2 \% відносно початкового показника. Зростання ПБЧ на 28 добу експерименту в групі комбінаці ібупрофену з вінбороном перевищувало аналогічні показники при монотерапі ібупрофеном і становило відповідно 15,9\% та 39,2 \%. Це свідчить про здатність вінборону потенціювати аналгетичний ефект ібупрофену за рахунок наявності у нього протизапально, знеболювально та спазмолітично активності [20, 21, 22, 23, 24].

У процесі експерименту ми визначали в динаміці масу тіла тварин. Було встановлено, що на 28 добу експерименту в групі тварин з AA, 
Оеляди літератури, ориаінальні дослідження, поеляд на проблему

лікованих комбінацією ібупрофену з вінбороном, динаміка приросту маси тіла відносно початку експерименту статистично вірогідно перевищувала аналогічний показник при монотерапі ібупрофеном і становила відповідно 9,6\% та 1,3\%, що також свідчить про високі захисні властивості вінборону в профілактиці ульцерогенно ді ібупрофену.

Крім того, нами було встановлено, що ВІ для групи ібупрофену майже в 10 разів перевищував даний показник в групі комбінованого застосування ібупрофену з вінбороном та становив відповідно 0,97 та 0,1. Це свідчить про високі захисні властивості вінборону та доцільність його застосування в комплексній терапі РА.

У ході проведеного дослідження нами було також зафіксовано 2 випадки летальності на 21

\section{ЛІТЕРАТУРА}

1. Катеренчук I. П. Гострий і хронічний суглобовий біль: оптимізація терапі нестеро дними протизапальними засобами в загальнолікарській практиці / . П. Ктеренчук, Т. І. Ярмола // Практикуючий лікар. - 2014. - № 1. C. 53-60.

2.Каратеев А. Е. Нестероидные противовоспалительные препараты в современной клинической практике: «за» больше, чем «против» [Текст] / А. Е. Каратеев // Современная ревматология. - 2008. - № 1. - С. 70-78.

3. Щокіна К. Г. Досягнення і перспективи вивчення сучасних нестеро дних протизапальних препаратів / К. Г. Щокіна // Клінічна фармація. - 2009. - Т. 13, № 2. C. $14-19$

4. Жураховская Д. В. Обоснование методического подхода к исследованию рациональности использования нестероидных противовоспалительных препаратов : дис. на соискание ученой степени каңд. фарм. наук: 14.04.03/ Д. В. Жураховская; ГБОУ ВПО «Российский университет дружбы народов», - Москва, 2014. - 207 с.

5. Циммерман Я. С. Гастродуоденальные эрозивноязвенные повреждения, индуцированные приемом нестероидных противовоспалительных препаратов [Текст] / Я. С. Циммерман, И. Я. Циммерман // Клиническая медицина : научно- практический журнал. - 2008. - № 2. C. $8-14$.

6. Халикова Л. А. Безопасность нестероидных противовоспалительных средств в условиях экспериментального повреждения костной ткани / Л. А. Халикова, В. Й. Мамчур // Укра нський журнал клінічно та лабораторно медицини. - 2010. - Т. 5, № 4. - С. 159-163.

7. Нестероидные противовоспалительные средства : анастезиологическая эффективность и основы безопасного применения (обзор литературы) / Р. И. Григорович, Е. А. Немахова, А. А. Лаврентьева, П. А. Попов // Вестник новых медицинских технологий. - 2010. - Т. 18, № 2. C. $175-179$.

8.Боль и проблема безопасности НПВС [Текст] : монография / А. В. Курята, Т. К. Лысунец, А. В. Зайченко, А. В. Черкасов. - Днепропетровск, 2014.

9. Морозова Т. Е. Ибупрофен: безопасность и эффективность применения в широкой клинической практике / та 22 добу експерименту в групі монотерапі ібупрофеном, внаслідок перфораці виразкових дефектів слизово оболонки шлунка. В групі комбінованого застосування ібупрофену та вінборону загибелі тварин не відмічалось.

Висновки. Вінборон проявив себе як препарат, здатний потенціювати аналгетичну активність ібупрофену при лікуванні експериментального АA у щурів. На це вказувало зростання ПБЧ на 28 добу експерименту, який вдвічі перевищував аналогічні показники при монотерапі, відповідно на 39,2 \% та 15,9 \%. Крім того, вінборон показав спроможність послаблювати ульцерогенний ефект ібупрофену, про що свідчили позитивна динаміка маси тіла, зменшення ВІ майже в 10 раз та відсутність летальності тварин.

Т. Е. Морозова, Т. Б. Андрушишина, Е. К. Антипова // Терапевтический архив. - 2013. - № 3. - С. 118-123.

10. «Вінборон» - новий вітчизняний спазмолітик з гастропротекторною дією [Текст] / Н. Г. Чорноіван, В. М. Чернобровий, Г. І. Степанюк [та ін.] // Сучасна гастроентерологія. - 2010. - № 3 (53). - С. 54-57.

11. Морозова Т. Е. Ибупрофен в практике врача терапевта : возможности в купировании болевых синдромов / Т. Е. Морозова, С. М. Рыкова // Лечащий врач. 2013. - № 1. - С. 75-79.

12. Рыболовлев Ю. Р. Дозирование веществ для млекопитающих по константам биологической активности / Ю. Р. Рыболовлев, Р. С. Рыболовлев // Доклады Академии Наук СССР. - 1979. - Т. 247, № 6. - С. 1513-1516.

13. Ноздрачев А. Д. Анатомия крысы (лабораторные животные) / А. Д. Ноздрачев, Е. Л. Поляков ; под. ред. академика А. Д. Ноздрачева. - СПб. : Издательство «ань», 2001. - $464 \mathrm{c}$

14. Тринус Ф. П. Нестероидные противовоспалительные средства : монография / Ф. П. Тринус, Н. А. Мохорт, Б. М. Клебанов - К. : Здоров'я, 1975 - 239 с.

15. Изменение болевой чувствительности у крыс при моделировании заболеваний костно- суставной системы на фоне применения Индотрила // Е. А. Подплетняя, И. А. Мазур, В. И. Мамчур [и др.] // Актуальні питання фармацевтично і медично науки та практики. - 2011. Вип. XXIV, №12. - С. 4-8.

16. Захаревский А. С. Влияние некоторых производных индола на нервную систему : дис. на соискание ученой степени канд. мед наук / А. С. Захаревский. - Минск, 1969. - С. 78-80.

17. Стефанов О. В. Доклінічні дослідження лікарських засобів : метод. рекоменд. / О. В. Стефанов, Л. В. Яковлева [та ін.]. - Ки в, 2001. - С. 321-333.

18. Катеренчук І. П. Побічні ефекти не стеро дних протизапальних засобів та х оптимальний вибір у практиці сімейного лікаря / І. П. Катеренчук // Сімейна медицина. - 2010. - № 1. - С. 19-28.

19. Табеева Г. Р. Ибупрофен в лечении нейрогенного болевого синдрома [Текст] / Г. Р. Табеева // Consiliun nedicum. - 2006. - T. 8, № 2. - C. 80-83. 
Оеляди літератури, оригінальні дослідження, поеляд на проблему

20. Експериментальне дослідження спазмолітичних властивостей вінборону / Н. І. Іванова, Г. І. Степанюк // Фенікаберан (вінборон) і бензофурака н: нові підходи до фармакотерапі запальних та ішемічних процесів : мат. наук.-практ. конф. - Вінниця : Тезис, 2000. - С. 33-34.

21. Степанюк Г. І. Вінборон - лікарський засіб з політропними фармакологічними властивостями : монографія / Г. І. Степанюк, О. О. Пентюк, Р. П. Піскун. Вінниця : Континент-Прим, 2007-243 с.

22. Чорноіван Н. Г. Вплив вінборону на гастротоксичність диклофенаку в експерименті [Текст] / Н. Г. Чор- ноіван // Фармакологія та лікарська токсикологія. 2009. - № 8. - С. 39-43.

23. Гордійчук А. Б. Токолітичні властивості вінборону (експериментальне дослідження) : автореф. дис. канд. мед. наук : 14.03.05. «Фармакологія» / Андрій Борисович Гордійчук ; ОДМУ - Одеса, 2006. - 19 c.

24. Гордієнко В. В. Зміни показників екскреторно функці нирок у щурів під впливом вінборону / В. В. Гордієнко, Р. Б. Косуба // Клінічна та експериментальна патологія. -2014 . - Т. XIII, № 2. - С. 47-51.

\title{
EFFECT OF VINBORON ON ANALGESIC IBUPROFEN ACTIVITY FOR MODELS OF ADJUVANT ARTHRITIS IN RATS
}

\author{
(CF. V. Hladkykh, N. H. Stepaniuk \\ Vinnytsa National Pyrohov Medical University by M. I. Pyrohov
}

SUMMARY. Experimentally that is able to potentiate vinboron analgesic activity of ibuprofen in the treatment of adjuvant arthritis (AA). This indicated increase in pain threshold on day 28 of the experiment in the treatment of AA combination with ibuprofen vinboron which twice exceeded the monotherapy. In addition vinboron showed the ability to weaken the ulcerogenic effect of ibuprofen, as evidenced by the dynamics of body mass index and mortality ulcerative animals.

KEYWORDS: adjuvant arthritis, NSAIDs, ibuprofen, vinboron, analgesic activity. 